\title{
ACCUMULATION POTENTIAL AND NUTRIENT CYCLING OF APPLE OF PERU (Nicandra physalodes) ${ }^{1}$
}

\author{
CHRISTIANO DA CONCEIÇÃO DE MATOS ${ }^{2 *}$, ELIZZANDRA MARTA MARTINS GANDINI ${ }^{3}$, EULÁLIA \\ APARECIDA SILVA ${ }^{3}$, JOSÉ BARBOSA DOS SANTOS ${ }^{4}$, EVANDER ALVES FERREIRA $^{4}$
}

\begin{abstract}
Weed residues can influence nutrient cycling in agroecosystems. Quantifying this potential nutrient source may influence weed control and fertilisation practices. Nicandra physalodes (L.) Gaertn. is a weed with a short life cycle and a great ability to accumulate dry matter. Field observations suggest that $N$. physaloides residues are easily decomposed in soil. The objective of this study was to evaluate the effect of increasing of $\mathrm{N}, \mathrm{P}$ and $\mathrm{K}$ doses on the growth of $N$. physalodes, as well as the nutrient content, chemical characteristics and $\mathrm{C} / \mathrm{N}$ ratio of the weed. A randomised block design, arranged in split-plot with three replications, was utilised. The main plots were given four doses of NPK (Dose $1-0,0.3$ and $17.2 \mathrm{mg} \mathrm{dm}^{-3}$; Dose $2-30,450.3$ and $75.4 \mathrm{mg} \mathrm{dm}^{-3}$; Dose $3-60,900.3$ and $133.4 \mathrm{mg} \mathrm{dm}^{-3}$; and Dose $4-120,1800.3$ and $\left.249.68 \mathrm{mg} \mathrm{dm}^{-3}\right)$, and the subplots were harvested at ten time points after emergence $(26,33,40,47,54,61,76$, 91, 106 and 121 days). Higher dry matter production and N, P and K content were observed in plants grown on higher levels of fertiliser. The increase of N, P and K levels in the soil resulted in greater total accumulation of these macronutrients. The highest macronutrient contents were $\mathrm{K}$ and $\mathrm{N}$. The treatments did not affect neutral detergent fibre (NDF), acid detergent fibre (ADF) and $\mathrm{C} / \mathrm{N}$ ratio of plant. $N$. physalodes had low $\mathrm{C} / \mathrm{N}$ ratio, low $\mathrm{NDF}$ and ADF levels, and great nutrient accumulation, suggesting that this plant is quickly decomposed, providing a rapid cycling of nutrients.
\end{abstract}

Keywords: Apple of Peru. Acid detergent fibre. $\mathrm{C} / \mathrm{N}$ ratio. Neutral detergent fibre.

\section{POTENCIAL DE ACÚMULO E CICLAGEM DE NUTRIENTES DE JOÁ-DE-CAPOTE (Nicandra physalodes)}

RESUMO - Os resíduos de plantas daninhas são importantes para a ciclagem de nutrientes nos agroecossistemas. A quantificação desta potencial fonte de nutrientes pode influenciar o manejo dessas plantas e as práticas de adubação. Nicandra physalodes (L.) Gaertn. (joá-de-capote) é uma planta daninha de ciclo curto com rápido crescimento e grande capacidade de acumular biomassa. Dessa forma, objetivou-se conhecer o potencial de acúmulo e ciclagem de nutrientes de $N$. physalodes e avaliar se o aumento de nitrogênio $(\mathrm{N})$, fósforo $(\mathrm{P})$ e potássio $(\mathrm{K})$ no solo influenciam essas características. Utilizou-se delineamento de blocos casualizados, arranjado em parcelas subdivididas com três repetições. As parcelas foram constituídas de quatro doses crescente de N, P e K (Dose 1 - 0, 0,3 e 17,2; Dose 2 - 30, 450,3 e 75,4; Dose 3 - 60, 900,3 e 133,4 e Dose $4-120,1800,3$ e 249,68 $\left.\mathrm{mg} \mathrm{dm}^{-3}\right)$ e as subparcelas de dez épocas de coleta das plantas $(26,33,40,47$, 54, 61, 76, 91, 106 e 121 dias após emergência). O aumento nos níveis de N, P e K no solo proporcionou maiores produções de massa seca e acúmulo total desses macronutrientes em plantas de $N$. physalodes, sendo que os maiores acúmulos foram de $\mathrm{K}$ e N. A adubação não influenciou os teores de fibra em detergente neutro (FDN), fibra em detergente ácido (FDA) e a relação carbono/ nitrogênio da planta. $N$. physalodes apresenta baixa relação $\mathrm{C} / \mathrm{N}$, o que aliado aos baixos teores de FDN e FDA e ao bom acúmulo de nutrientes, sugere que o material vegetal dessa planta seja rapidamente decomposto, proporcionando uma ciclagem rápida de nutrientes no solo.

Palavras-chave: Joá-de-capote. Fibra em detergente neutro. Relação C/N. Fibra em detergente ácido.

\footnotetext{
${ }^{*}$ Corresponding author

${ }^{1}$ Received for publication in 02/03/2017; accepted in 06/06/2017.

Extracted from the first author's Master's dissertation.

${ }^{2}$ Department of Crop Science, Universidade Federal de Viçosa, Viçosa, MG, Brazil; christianomts@gmail.com.

${ }^{3}$ Department of Forest Engineering, Universidade Federal dos Vales do Jequitinhonha e Mucuri, Diamantina, MG, Brazil; elizzandragandini@yahoo.com.br, eulalia.a.silva@gmail.com.

${ }^{4}$ Department of Agronomy, Universidade Federal dos Vales do Jequitinhonha e Mucuri, Diamantina, MG, Brazil; jbarbosasantos@yahoo.com.br, evanderalves@gmail.com.
} 


\section{INTRODUCTION}

The need to increase global food production (LONG et al., 2015; RAY et al., 2013) has led to an increased use of synthetic fertilisers, especially $\mathrm{N}, \mathrm{P}$ and $\mathrm{K}$ macronutrients in agriculture. This increase in the soil's agricultural fertilisation has accelerated the depletion of non-renewable nutrient sources, mainly $\mathrm{P}$ and $\mathrm{K}$, and increased the cost of fertilisers (RENWICK et al., 2012; XU et al., 2014). There are estimates that the current rates of $\mathrm{P}$ extraction may lead to global exhaustion of about $20-60 \%$ of phosphate rock by the year 2100 (VAN VUUREN et al., 2010). In this perspective, a single country (Morocco) will be responsible for $80 \%$ of the total $\mathrm{P}$ production in the world (COOPER et al., 2011). On the other hand, $\mathrm{K}$ is the seventh or eighth most abundant element on the earth (ZÖRB et al., 2014), and the world's reserve of this element is estimated at approximately 9.5 billion tons (RENWICK et al., 2012). Despite this, in view of the current rate of $\mathrm{K}$ production, it is estimated that $\mathrm{K}$ reserves will be exhausted in less than 300 years (RENWICK et al., 2012). Thus, new nutrient sources need to be found to meet the global food requirement and decrease reliance on external inputs (LINDSEY et al., 2013). Sustainable food production will depend on correct mineral fertiliser use and plant residue management to maximise the yield and economic return of agricultural activities (TILMAN et al., 2002).

Plant residue management is essential in agroecosystem because it interferes with the physical, chemical and biological properties of soils (CHEN et al., 2014). Plant residue contributions, mainly of cover crops, to the soil's nutrient availability have been studied extensively (CHEN et al., 2014), and plant residues can provide sufficient nutrients in the soil to fully or partially meet the crop requirements (DAMON et al., 2014).

It is known that some weeds are able to accumulate large amounts of nutrients in their tissues, which make them a potential nutrient source to the soil, by the nutrient cycling of their residues (LINDSEY et al., 2013; SAKONNAKHON et al., 2006). The accumulation of $\mathrm{K}, \mathrm{Mg}$ and $\mathrm{P}$ was higher in weeds (weed vegetation site) than in the Leguminosae species Crotalaria juncea, Crotalaria spectabilis, Cajanus cajan, Canavalia ensiforme, Dolichos lablab and Mucuna aterrima, used as cover crops (CAVALCANTE et al., 2012). Information about weed nutrient contents and their $\mathrm{C} / \mathrm{N}$ ratios can be used as a basis for interpretations of the behaviour of these plants in agroecosystems (LINDSEY et al., 2013). In addition, the chemical composition of plant tissues regulates their decomposition rate and determines the soil nutrient cycling (CHACÓN et al., 2011; CHEN et al., 2014; HARRE et al., 2014).

Information on weed nutrient allocation and concentration is required to understand the ability of weeds to cycle nutrients in agroecosystems and to reduce nutrient losses during the non-crop fallow period (SAKONNAKHON et al., 2006). Although the contribution of weed residues to the nutrient balance in agroecosystems is still poorly understood, the release of $\mathrm{N}$ from the weed residues may contribute to the soil $\mathrm{N}$ pool during the crop growing season (HARRE et al., 2014; LINDSEY et al., 2013).

Nicandra physalodes (L.) Gaertn. (Solanaceae), known as the "apple of Peru" (WATANABE et al., 2002), is a herbaceous plant native to Peru that can now be found in several regions of the world. It is an annual sub-bush, erect and fast growing, popularly known in Brazil as quintilho, joá-de-capote, bexiga, balãozinho or lanterna-da-china (KISSMANN; GROTH, 2000). $N$. physalodes produces a large amount of seeds, but only about $25 \%$ are viable after fruit maturation; hence, this plant is often found throughout Brazil, infesting areas of annual and perennial crops (LORENZI, 2006), as is also reported for soybean (NEPOMUCENO et al., 2007), cotton (BRAZ et al., 2011) and okra (BACHEGA et al., 2013). This is a withanolide-rich plant, which has antifeedants, insecticide, antitumor (TOMASSINI et al., 2000) and antifungal (MUKUNGU et al., 2013) effects. Moreover, aqueous extracts of $N$. physaloides have been used to measure the synthesis of silver nanoparticles, which are successful in the control of mosquito larvae of Anopheles stephensi, Aedes aegypti and Culex quinquefasciatus (GOVINDARAJAN et al., 2016). Despite this, there are few studies on $N$. physaloides biology.

Some horticulturists in Diamantina-MG, Brazil, have managed areas infested with $N$. physalodes by maintaining residues of this plant on the soil, after control, since this practice contributes to the growth of vegetables. $N$. physalodes growth analysis showed that this plant has a fast cycle, adapts well to fertile soils and has great capacity to accumulate dry matter (MATOS et al., 2015). This indicates that, if $N$. physalodes is well managed, its residues can contribute to the nutrient supply (through decomposition) and decrease nutrient losses of the soil in areas infested by it. Thus, the aim of this study was to evaluate the N, P and $\mathrm{K}$ dose effects on $N$. physalodes growth, as well as the nutrient content, chemical characteristics and $\mathrm{C} / \mathrm{N}$ ratio of this weed.

\section{MATERIAL AND METHODS}

The experiment was carried out in a greenhouse of the "Departamento de Agronomia" of the "Universidade Federal dos Vales do Jequitinhonha e Mucuri” (UFVJM), Diamantina-MG, in May and September 2012. Nicandra physalodes seeds were collected from the experimental field of UFVJM 
Diamantina-MG. Seed dormancy was broken by immersing and washing in water to remove the mucilage, as described by Matos et al. (2015).

Dry seeds were germinated on a plastic tray containing soil. At 25 days after sowing, each $N$. physalodes seedling was transplanted to a $8-\mathrm{dm}^{3}$ plastic pot containing soil with the following physical and chemical properties: $\mathrm{pH}$ (water) of 6.1 ; organic matter content of $1000 \mathrm{mg} \mathrm{dm}^{-3}$; clay content of $110,000 \mathrm{mg} \mathrm{dm}^{-3}$; $\mathrm{P}$ and $\mathrm{K}, 0.3$ and $17.2 \mathrm{mg} \mathrm{dm}^{-3}$, respectively; and $\mathrm{Ca}, \mathrm{Mg}, \mathrm{Al}, \mathrm{Al}$ and cation-exchange capacity of $13,3,0.2,19$ and $16.6 \mathrm{mmol} \mathrm{dm}^{-3}$, respectively.
The treatments were arranged in a randomised block design with three replications in a split-plot arrangement (4 fertiliser doses x 10 plant harvest times). NPK treatments were applied in each experimental plot in four levels: 0 (L1), 0.5 (L2), 1 (L3) and 2 (L4) times the dose recommended by Cantarutti et al. (2007) (Table 1). The subplots were collected at 10 harvest times $(26,33,40,47,54,61$, $76,91,106$ and 121 days after emergence (DAE)). We used ammonium sulphate $(45 \%$ of $\mathrm{N})$, simple superphosphate $\left(18 \%\right.$ of $\left.\mathrm{P}_{2} \mathrm{O}_{5}\right)$ and potassium chloride $\left(60 \%\right.$ of $\left.\mathrm{K}_{2} \mathrm{O}\right)$ applied one day before $N$. physalodes transplanting.

Table 1. N, P and K levels in soils, utilised as treatments.

\begin{tabular}{cccc}
\hline \multirow{2}{*}{ Treatments } & \multicolumn{3}{c}{ Nutrient levels $\left(\mathrm{mg} \mathrm{dm}^{-3}\right)$} \\
\cline { 2 - 4 } & $\mathrm{N}$ & $\mathrm{P}$ & $\mathrm{K}$ \\
\hline L1 & 0 & 0.3 & 17.2 \\
L2 & 30 & 450.3 & 75.4 \\
L3 & 60 & 900.3 & 122.4 \\
L4 & 120 & 1800.3 & 249.68 \\
\hline
\end{tabular}

At each harvest, N. physalodes roots and shoots were washed in water and put in a fan-forced oven at $65^{\circ} \mathrm{C}$, where they remained until they reached constant weight. These plant materials were weighed using a precision balance (Marte/ Shimadzu ${ }^{\circledR}$ BL320-H) to determine the dry matter. Plant tissues (roots, leaves, stems and reproductive organs) were ground in an analytical mill for quantification of $\mathrm{C}, \mathrm{N}, \mathrm{P}$ and $\mathrm{K}$ concentrations. Phosphorus and potassium were measured after digestion with a mixture of nitric and perchloric acids. $P$ concentration was determined by colourimetry method through the formation of the blue colour of the phosphate-molybdate complex in the presence of ascorbic acid, and $\mathrm{K}$ concentration was determined by spectrophotometry flame emission (MALAVOLTA et al., 1997). C and N concentrations were determined in a LECO TruSpec Micro Element Analyzer using the following reference materials: Orchard Leaves lot n. 1032 and Cystine lot n. 1054. The analyser uses helium and oxygen as the drag and ignition gas, respectively. The 2-mg plant tissue samples were placed in tin capsules and incinerated at $1075^{\circ} \mathrm{C}$.

Plant tissue total nutrient accumulation ( $\mathrm{g}$ plant $^{-1}$ ) was calculated by multiplying the N, P and $\mathrm{K}$ concentrations ( $\mathrm{g}$ nutrient per $\mathrm{g}$ of dry matter) with the total dry matter.

For determination of the neutral detergent fibre (NDF), $0.5 \mathrm{~g}$ of ground plant tissues were placed in $5.5 \times 10 \mathrm{~cm}$ TNT (non-woven tissue) bags, previously washed, dried and weighed. These samples were autoclaved for $60 \mathrm{~min}$ at $1 \mathrm{~atm}$ pressure, kept in neutral detergent solution for another $60 \mathrm{~min}$, washed successively with hot distilled water and acetone, dried and weighed on a precision balance scale (Shimadzu ${ }^{\circledR}$ AY-220). Subsequently, the TNT bags with the samples were placed in acid detergent solution for $60 \mathrm{~min}$ to quantify the levels of acid detergent fibre (ADF) (VAN SOEST et al., 1991).

The concentrations of NDF, ADF, N, P, K and $\mathrm{C}$ were not measured for $N$. physalodes grown in the L1 soil condition, since it did not produce sufficient dry matter for such analyses during the entire development cycle of the plant. For the same reason, these evaluations were not performed for $N$. physalodes grown in the L2, L3 and L4 soil conditions, when the plants were harvested at 26, 33 and 40 DAE.

The data obtained were tested for normality and homogeneity of variance and then submitted to analysis of variance by the $\mathrm{F}$ test. When the result was significant, regression analysis was performed. The regression model was chosen by statistical significance ( $\mathrm{F}$ test), coefficient of determination $\left(\mathrm{R}^{2}\right)$ and the biological significance of the model.

\section{RESULTS AND DISCUSSION}

There were significant interactions between nutrient levels and harvesting times $(\mathrm{p}<0.05)$ in total dry matter, $\mathrm{N}, \mathrm{P}$ and $\mathrm{K}$ accumulation, $\mathrm{NDF}$, and $\mathrm{C} / \mathrm{N}$ ratio of $N$. physalodes (Table 2). Unpacking these 
interactions allowed regression equations for harvesting time to be adjusted at each level of $\mathrm{N}, \mathrm{P}$ and $\mathrm{K}$. On the other hand, there was no significant interaction between the levels of $\mathrm{N}, \mathrm{P}$ and $\mathrm{K}$ and harvest times for the ADF content of $N$. physalodes (Table 2). For this variable, an equation model was fitted for the harvest times $(\mathrm{p}<0.05)$.

Table 2. Summary of the analysis of variance for the total dry matter accumulation (TDM), nitrogen (N), phosphorus (P) and potassium (K), neutral detergent fibre (NDF), acid detergent fibre (ADF), and carbon/nitrogen ratio (C/N) of Nicandra physalodes.

\begin{tabular}{|c|c|c|c|c|c|c|c|c|c|}
\hline \multirow{2}{*}{$\begin{array}{l}\text { Source of } \\
\text { variation }\end{array}$} & \multicolumn{3}{|c|}{ Calc. F } & \multicolumn{6}{|c|}{ Calculated F } \\
\hline & DF & TDM & DF & $\mathrm{N}$ & $\mathrm{P}$ & $\bar{K}$ & NDF & $\mathrm{ADF}$ & $\mathrm{C} / \mathrm{N}$ \\
\hline Block & 2 & $1.13^{\mathrm{ns}}$ & 2 & $1.34^{\mathrm{ns}}$ & $0.57^{\mathrm{ns}}$ & $1.74^{\mathrm{ns}}$ & $1.50^{\mathrm{ns}}$ & $2.59^{\mathrm{ns}}$ & $0.73^{\mathrm{ns}}$ \\
\hline Level (L) & 3 & $64.24^{* *}$ & 2 & $36.99^{* *}$ & $35.26^{* *}$ & $33.16^{* *}$ & $3.91^{\mathrm{ns}}$ & $0.65^{\mathrm{ns}}$ & $15.03^{*}$ \\
\hline Error 1 & 6 & & 4 & & & & & & \\
\hline Harvest $(\mathrm{H})$ & 9 & $78.17^{* *}$ & 6 & $15.22^{* *}$ & $21.22^{* *}$ & $12.12^{* *}$ & $122.47^{* *}$ & $153.26^{* *}$ & $140.55^{* *}$ \\
\hline $\mathrm{L} \times \mathrm{H}$ & 27 & $17.69^{* *}$ & 12 & $3.03^{* *}$ & $4.42^{* *}$ & $3.61^{* *}$ & $2.22^{*}$ & $1.18^{\mathrm{ns}}$ & $4.18^{* *}$ \\
\hline Error 2 & 72 & & 36 & & & & & & \\
\hline Total & 119 & & 62 & & & & & & \\
\hline CV $1(\%)$ & & 58.54 & & 39.90 & 44.93 & 38.36 & 5.50 & 7.87 & 7.80 \\
\hline CV $2(\%)$ & & 31.29 & & 26.60 & 21.42 & 21.52 & 8.28 & 9.64 & 7.13 \\
\hline
\end{tabular}

$\mathrm{DF}=$ degrees of freedom; $\mathrm{ns}=$ not significant; $* *, *=$ significant by the $\mathrm{F}$ test at $\mathrm{p} \leq 0.01$ and $\mathrm{p} \leq 0.05$, respectively; $\mathrm{CV}=$ coefficient of variation.

The total dry matter accumulation of $N$. physalodes was proportional to the increase of nutrient levels in the soil (Figure 1). This plant reached the maximum dry matter accumulation between 61 and 76 DAE, when cultivated in fertilised soil. The low fertility of the soil used in this experiment contributed to the lower dry matter accumulation in $N$. physalodes grown in the L1 soil condition.

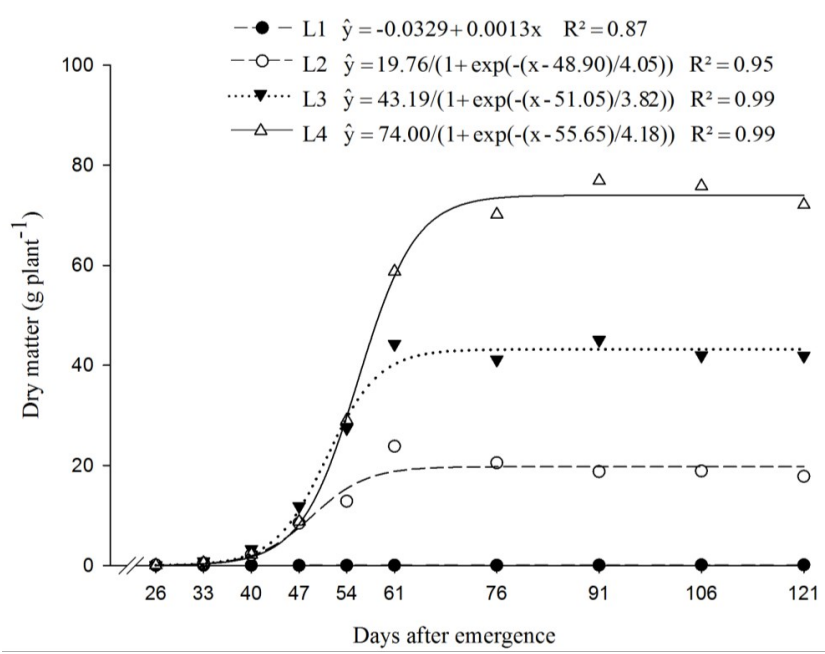

Figure 1. Total dry matter accumulation in Nicandra physalodes over the life cycle in four treatments of N, P and $\mathrm{K}$. Treatments were: (L1) 0, 0.3, $17.2 \mathrm{mg} \mathrm{dm}^{-3} \mathrm{~N}, \mathrm{P}, \mathrm{K}$; (L2) 30, 450.3, $75.4 \mathrm{mg} \mathrm{dm}^{-3} \mathrm{~N}, \mathrm{P}, \mathrm{K}$; (L3) 60, 900.3, $133.4 \mathrm{mg} \mathrm{dm}^{-3}$ $\mathrm{N}, \mathrm{P}, \mathrm{K}$; and (L4) $120,1800.3,249.68 \mathrm{mg} \mathrm{dm}^{-3} \mathrm{~N}, \mathrm{P}, \mathrm{K}$.

The increase of dry matter of $N$. physalodes cultivated in fertilised soil can be explained by the fact that N, P and $\mathrm{K}$ are essential for the plant development: $\mathrm{N}$ has a structural function, is a constituent of amino acids, proteins, chlorophyll, and vegetal hormones, etc. (MASCLAUX-DAUBRESSE et al., 2010); P participates in the processes of energy generation, nucleic acid synthesis, photosynthesis, glycolysis, respiration, membrane synthesis, enzyme activation or inactivation, redox reactions, carbohydrate metabolism, and $\mathrm{N}$ fixation (VANCE et al., 2003); and $\mathrm{K}$ is an activator of more than 40 enzymes, besides being the main cation responsible for the maintenance of turgor and cellular electroneutrality of the plant (ZÖRB et al., 2014).

The inflorescence emission (Figure 2A) in $N$. physalodes started from $21 \mathrm{DAE}$, and the onset of anthesis was observed close to 35 DAE. Flowering occurred practically during ever over the $N$. physalodes life cycle. Plant concentrated flowering at around 61 DAE, when dry matter 
allocation to the fruits was intensified (MATOS et al., 2015). At that time, the gradual process of yellowing, senescence and abscission of N. physalodes leaves was initiated (Figure 2B). This phenomenon began with the completely expanded and mature leaves of the lower third of the N. physalodes and developed until the plant was completely defoliated at 121 DAE (Figure 2C). At
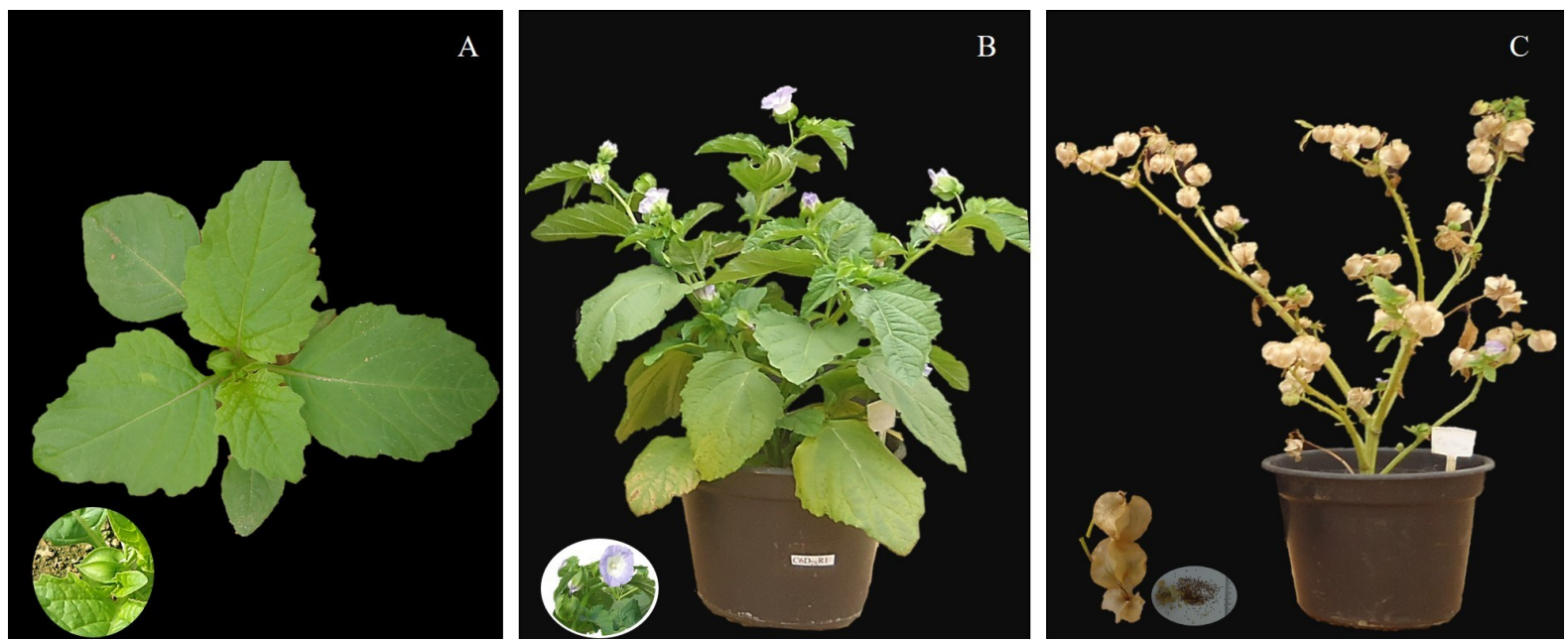

Figure 2. Nicandra physalodes pictures at 26 (A), 61 (B) and 121 (C) days after emergence (DAE), grown on soil fertilised with the highest $\mathrm{N}, \mathrm{P}$ and $\mathrm{K}$ levels $\left(120,1800.3\right.$ and $249.68 \mathrm{mg} \mathrm{dm}^{-3}$ of $\mathrm{N}, \mathrm{P}$ and $\mathrm{K}$, respectively). At $26 \mathrm{DAE}$, plants with only six leaves had already begun the flowering process. In detail in the picture (A) is the first flower bud of the plant. At $61 \mathrm{DAE}, N$. physalodes was close to its maximum dry matter accumulation and had reproductive organs at different stages. Details (B) of fully opened flowers and fruits at the beginning of development. Also, the beginning of yellowing of the leaves of the lower third of the plant was observed. At 121 DAE (C), plants were observed with virtually no leaves, but was loaded with fruit, the majority of which were dry. During the ripening process, fruit dehydrate and change from green to a straw-yellow colour. In detail, the $N$. physalodes dry fruit and the large amount of seeds contained in a single fruit. The pictures are illustrative and are not to scale according to the growth stage of the plant. Additional information on $N$. physalodes growth, such as dry matter allocation pattern, relative growth rate, height and leaf area over the life cycle of N. physalodes were reported by Matos et al. (2015).

The accumulation of $\mathrm{N}, \mathrm{P}$ and $\mathrm{K}$ in $N$. physalodes increased with the level of fertilisation in the soil (Figure 3). The accumulation of $\mathrm{K}$ and $\mathrm{N}$ in this plant tissues was higher than that for $\mathrm{P}$ when compared in the same treatments (Figure 3).

The increase of the $\mathrm{N}, \mathrm{P}$ and $\mathrm{K}$ accumulation in $N$. physalodes is due to the higher levels of fertiliser increasing the availability of these elements in the soil, which favours the transportation of $\mathrm{P}$ and $\mathrm{K}$ to the plant roots by diffusion and $\mathrm{N}$ by mass flow, increasing the plant absorption (MARSCHNER, 2012). The higher accumulation of $\mathrm{N}$ and $\mathrm{K}$ that was observed in $N$. physalodes, was also reported in Merremia aegyptia (MARTINS et al., 2010) and Solanum americanum (BIANCO et al., 2012).

The total $\mathrm{N}$ content in $N$. physalodes increased to $61 \mathrm{DAE}$, when it reached maximum values, with a subsequent decrease, independent of the N, P and $\mathrm{K}$ level in the soil (Figure 3A). The decrease of the $\mathrm{N}$ content in $N$. physalodes can be explained by the accumulation of $30-51 \%$ of the total dry matter in the reproductive organs of this plant from 61 DAE (MATOS et al., 2015), since the $\mathrm{N}$ content in these organs was not measured.

The maximum total $\mathrm{P}$ accumulation in $N$. physalodes grown under the L3 and L4 soil conditions was about 215 and $392 \mathrm{mg} \mathrm{plant}^{-1}$, respectively, close to 76 DAE (Figure $3 \mathrm{~B}$ ). After this period, the weed showed a tendency to stabilise its total $\mathrm{P}$ accumulation.

The total $\mathrm{K}$ accumulation in $N$. physalodes grown in the L3 and L4 soil conditions increased during the plant growth period. The $\mathrm{K}$ accumulation rate was higher in $N$. physalodes cultivated in the L4 soil condition, but decreased with plant age, regardless of soil fertility (Figure $3 \mathrm{C}$ ). $\mathrm{K}$ is not metabolised in the plant and forms bonds with organic molecules of easy reversibility, with the inorganic ion being more abundant in plant cells (AHMAD; MAATHUIS, 2014). Thus, the K uptake and translocation by the xylem decreases, as the physiological activity of the plant is reduced (ZÖRB et al., 2014), which explains the reduction in the $\mathrm{K}$ accumulation rate with the age of $N$. physalodes. 


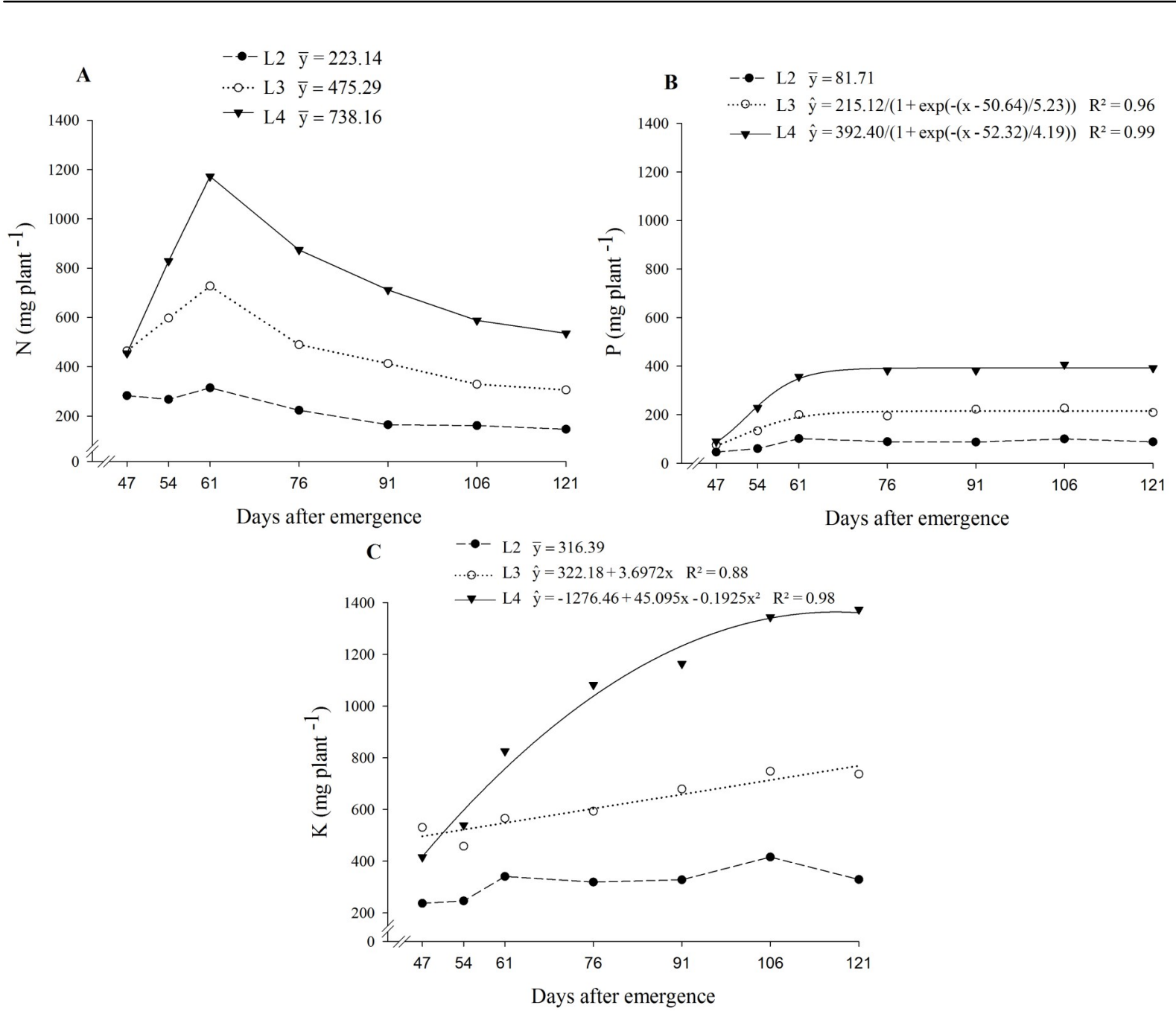

Figure 3. Total nitrogen (A), phosphorus (B) and potassium (C) accumulation in Nicandra physalodes over the life cycle in four treatments of N, P and K. Treatments were: (L1) 0, 0.3, $17.2 \mathrm{mg} \mathrm{dm}^{-3} \mathrm{~N}, \mathrm{P}, \mathrm{K}$; (L2) 30, 450.3, $75.4 \mathrm{mg} \mathrm{dm}^{-3} \mathrm{~N}, \mathrm{P}, \mathrm{K}$; (L3) $60,900.3,133.4 \mathrm{mg} \mathrm{dm}^{-3} \mathrm{~N}, \mathrm{P}, \mathrm{K}$; and (L4) 120, 1800.3, $249.68 \mathrm{mg} \mathrm{dm}^{-3} \mathrm{~N}, \mathrm{P}, \mathrm{K}$.

The total $\mathrm{P}$ and $\mathrm{K}$ accumulation in $N$. physalodes grown in the L2 soil condition was higher from $61 \mathrm{DAE}$, when this plant accumulated an average of 94 and $346 \mathrm{mg}$ plant $^{-1}$ of $\mathrm{P}$ and $\mathrm{K}$, respectively (Figures $3 \mathrm{~B}$ and $3 \mathrm{C}$ ).

The NDF and ADF contents increased linearly with $N$. physalodes growth time (Figure 4A and 4B). NDF represents the fibre portion (cellulose, hemicellulose and lignin) and the ADF represents the most recalcitrant fraction (cellulose and lignin) of the plant cell wall (ARYAL et al., 2015; VELAZQUEZJIMENEZ; RANGEL-MENDEZ, 2014). Plants increase their cell wall fibrous constituent contents (hemicelluloses, cellulose and lignin) with age (HARRE et al., 2014; ORTEGA-VARGAS et al., 2013), because during the plant ripening process, there is a thickening and lignification of the cell wall to support the tissues of the plant (HOFFMAN et al., 2007). This explains the increase of NDF and ADF contents in $N$. physalodes over its growth period.

The most labile components of the cell wall related to plant residue decomposition, in ascending order, are hemicellulose, cellulose and lignin (ESPINDOLA et al., 2006; KALBITZ et al., 2007; ZHOU et al., 2015). Thus, lower NDF and ADF concentrations are usually related to plant residues that have a fast decomposition rate and nutrient cycling in soil (RUFFO; BOLLERO, 2003). Therefore, young plant residues tend to decompose more quickly than residues from mature plants, as reported for Chenopodium album, Ambrosia artemisiifolia (LINDSEY et al., 2013), Amaranthus tuberculatus and Setaria faberi (HARRE et al., 2014). Thus, the sooner the control of $N$. physalodes is carried out, the greater the decomposition rate of its residue, regardless of the $\mathrm{N}, \mathrm{P}$ and $\mathrm{K}$ levels in the soil.

The $\mathrm{C} / \mathrm{N}$ ratio of $N$. physalodes increased up to $76 \mathrm{DAE}$, with a tendency to stabilise in later harvests (Figure 5). The maximum $\mathrm{C} / \mathrm{N}$ ratio was obtained close to $76 \mathrm{DAE}$, when average values of 20.56, 20.88 and 19.94 were observed for $N$. physalodes grown in L2, L3 and L4 soil conditions, respectively. 

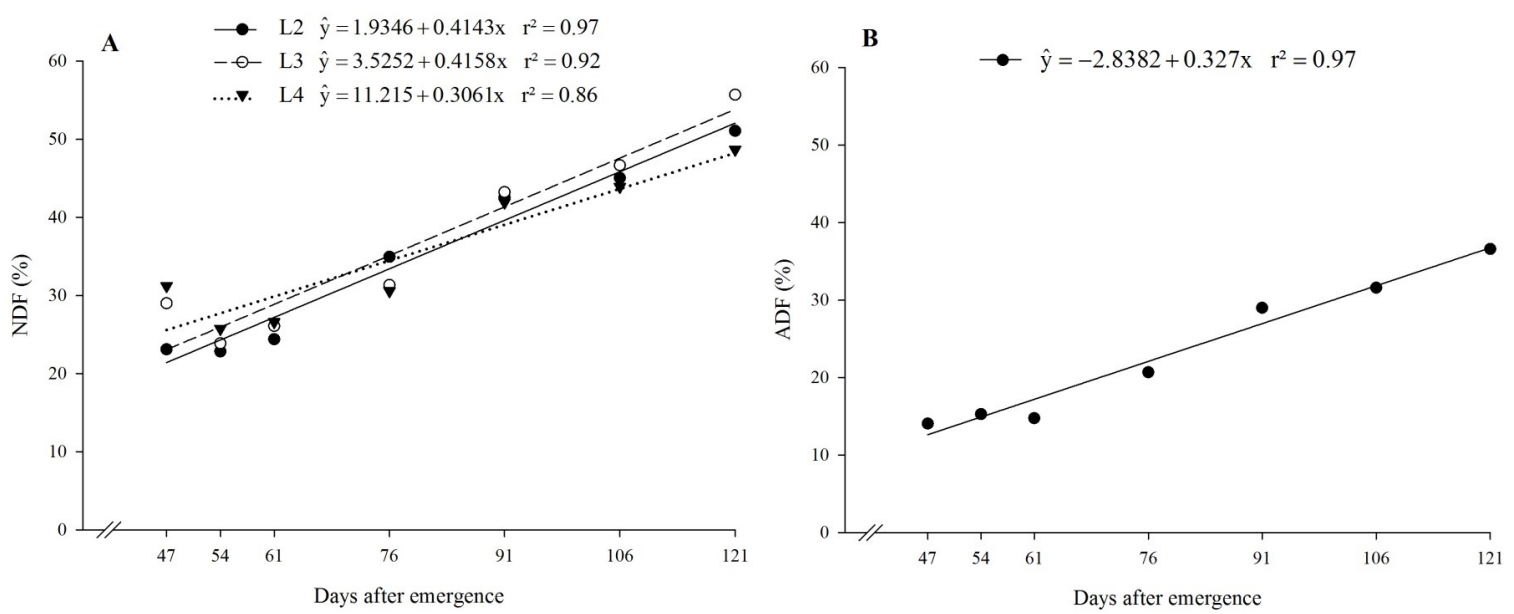

Figure 4. Neutral detergent fibre - NDF (A) and acid detergent fibre - ADF (B) in Nicandra physalodes over the life cycle in four treatments of N, P and K. Treatments were: (L1) 0, 0.3, $17.2 \mathrm{mg} \mathrm{dm}^{-3} \mathrm{~N}, \mathrm{P}, \mathrm{K}$; (L2) 30, 450.3, $75.4 \mathrm{mg} \mathrm{dm}^{-3} \mathrm{~N}, \mathrm{P}, \mathrm{K}$; (L3) 60, 900.3, $133.4 \mathrm{mg} \mathrm{dm}^{-3} \mathrm{~N}, \mathrm{P}, \mathrm{K}$; and (L4) 120, 1800.3, $249.68 \mathrm{mg} \mathrm{dm}^{-3} \mathrm{~N}, \mathrm{P}, \mathrm{K}$.

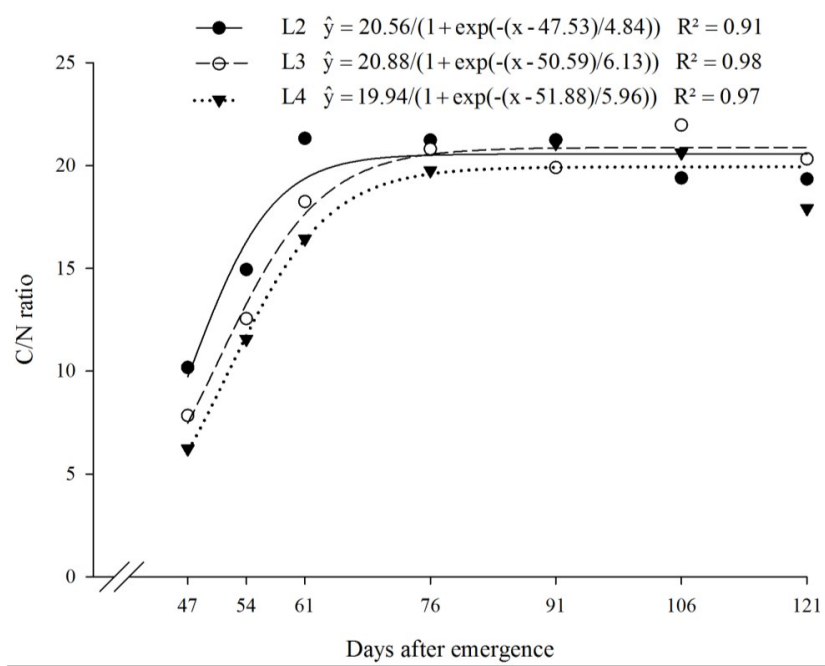

Figure 5. Carbon/nitrogen ratio $(\mathrm{C} / \mathrm{N})$ in Nicandra physalodes over the life cycle in four treatments of $\mathrm{N}, \mathrm{P}$ and $\mathrm{K}$. Treatments were: (L1) 0, 0.3, $17.2 \mathrm{mg} \mathrm{dm}^{-3} \mathrm{~N}, \mathrm{P}, \mathrm{K}$; (L2) 30, 450.3, $75.4 \mathrm{mg} \mathrm{dm}^{-3} \mathrm{~N}, \mathrm{P}, \mathrm{K}$; (L3) 60, 900.3, $133.4 \mathrm{mg} \mathrm{dm}^{-3}$ $\mathrm{N}, \mathrm{P}, \mathrm{K}$; and (L4) $120,1800.3,249.68 \mathrm{mg} \mathrm{dm}^{-3} \mathrm{~N}, \mathrm{P}, \mathrm{K}$.

The plant residue $\mathrm{C} / \mathrm{N}$ ratio controls its mineralisation-immobilisation pattern by the soil microbial biomass (BRUUN et al., 2006; REGEHR et al., 2015). Low $\mathrm{N}$ content, high $\mathrm{C} / \mathrm{N}$ ratio and high lignin and polyphenol contents in plant residues decrease the decomposition rate and increase the nutrient immobilisation by the soil microbiota (CHEN et al., 2014; YADVINDER-SINGH et al., 2005). Weed residues with a $\mathrm{C} / \mathrm{N}$ ratio less than 19 provided 25 to $45 \%$ of the total $\mathrm{N}$ concentration to the soil within two weeks. On the other hand, those residues with a $\mathrm{C} / \mathrm{N}$ ratio greater than 19 initially immobilised N (LINDSEY et al., 2013). This may render the $\mathrm{N}$ from the plant residue unavailable during the crop growing period. Thus, a $N$. physalodes $\mathrm{C} / \mathrm{N}$ ratio greater than 19 , after $76 \mathrm{DAE}$, can decrease the rate of $\mathrm{N}$ release of its residue. However, the mineralisation rate depends on the nutrient, as observed for A. tuberculatus and S. faberi residues, in which $\mathrm{K}$ was the nutrient released more easily and Ca was more retained (HARRE et al., 2014).

Fertilisation did not influence NDF or ADF concentrations of $N$. physalodes (Table 2). These results differ from those observed for Brachiaria brizantha var. Marandu when higher nitrogen levels in the soil decreased the NDF contents of this plant (MAGALHÃES et al., 2015). Nitrogen stimulates the growth of new tissues, increases the leaf developement and favours stem elongation to support the shoot, therefore decreasing plant fibre contents (MAGALHÃES et al., 2015). The increase of the N, P and K levels in the soil did not influence the dry matter allocation pattern in $N$. physalodes (MATOS et al., 2015), and this may have contributed to the formation of tissues with similar contents of fibres, $\mathrm{C}$ and $\mathrm{N}$ in $N$. physalodes.

The equilibrium condition, in which mineralisation is approximately equal to immobilisation, occurs when the organic material $\mathrm{C}$ / 
$\mathrm{N}$ ratio is in the range of 20 to 30 . In this case, the inorganic $\mathrm{N}$ availability of the soil is not affected (IPPOLITO; BARBARICK, 2003). Thus, it is common in soils with high $\mathrm{C} / \mathrm{N}$ ratios in the predominant plant residue, for there to be competition between plants and soil microorganims for the soil inorganic $\mathrm{N}$, which may lead to nutrient deficiency for the crops (CHEN et al., 2014). The low $\mathrm{C} / \mathrm{N}$ ratio values of $N$. physalodes, during its growth period, avoids this kind of competition if the $N$. physalodes residues will be added or maintained as cover in soils.

In general, regardless of treatment, plant residue from $N$. physalodes tends to slow the decomposition and nutrient cycling as the age of plants being managed increases. Although the average $\mathrm{C} / \mathrm{N}$ ratio of $N$. physalodes remains low $(<30)$ during its growth period, NDF and ADF increased with $N$. physalodes age, and therefore the tissues of this plant tend to have higher resistance to decomposition and nutrients.

The control of $N$. physalodes close to $61 \mathrm{DAE}$ is convenient when faster nutrient cycling is desired, since in this period the plant is close to its maximum dry matter accumulation, with good total N, P and K accumulation and with an average $\mathrm{C} / \mathrm{N}$ ratio of 16 . Moreover, at 61 DAE, $N$. physalodes did not have mature fruits. It is advisable that the control of this weed is carried out before the 91-DAE period, in which the fruit ripening intensifies (MATOS et al., 2015). This management can prevent the spread of this species in the area and the increase of the soil seed bank. However, in field conditions, this fruiting and ripening interval of $N$. physalodes fruits can be changed. In addition, studies are required for better understanding of the viability of $N$. physalodes seeds during fruit development.

Despite the potential in nutrient cycling and the ability to develop in excessively fertilised soils of $N$. physalodes, it should be emphasised that it is an aggressive weed that produces a large amount of dormant seeds. Therefore, once present in an area, $N$. physalodes can be difficult to eradicate because this species is able to persist in the soil seed bank for long periods of time. In this way, the introduction of $N$. physalodes into an area is dependent on studies of seed dormancy breaking techniques that allow high germination rates. Thus, it would be possible to manage this weed in order to avoid the formation of a seed bank in the soil, which would lead to a consequent persistence of the plant in the area.

\section{CONCLUSIONS}

Mineral fertilisation with $\mathrm{N}, \mathrm{P}$ and $\mathrm{K}$ increased the growth and accumulation of nutrients in $N$. physalodes, but did not influence the $\mathrm{C} / \mathrm{N}$ ratio, NDF or ADF concentrations of this plant. Moreover, $N$. physalodes had low $\mathrm{C} / \mathrm{N}$ ratios at different vegetative and reproductive phenological stages. These results - low $\mathrm{C} / \mathrm{N}$ ratio, low $\mathrm{NDF}$ and ADF concentrations, and high nutrient accumulation - suggest that $N$. physalodes residues have a fast decomposition rate and nutrient cycling in soil.

\section{ACKNOWLEDGEMENTS}

The authors would like to thank $\mathrm{CNPq}$ (Conselho Nacional de Desenvolvimento Científco e Tecnológico), FAPEMIG (Fundação de Amparo à Pesquisa do Estado de Minas Gerais) and CAPES (Coordenação de Aperfeiçoamento de Pessoal de Nível Superior) for fnancial support for this research.

\section{REFERENCES}

AHMAD, I.; MAATHUIS, F. J. M. Cellular and tissue distribution of potassium: Physiological relevance, mechanisms and regulation. Journal of Plant Physiology, Jena, v. 171, n. 9, p. 708-714, 2014.

ARYAL, A. et al. Foods, macronutrients and fibre in the diet of blue sheep (Psuedois nayaur) in the Annapurna Conservation Area of Nepal. Ecology and Evolution, New Jersey, v. 5, n. 18, p. 40064017, 2015.

BACHEGA, L. P. S. et al. Periods of weed interference in okra crop. Planta Daninha, Viçosa, v. 31, n. 1, p. 63-70, 2013.

BIANCO, S. et al. Acúmulo de massa seca e de macronutrientes por plantas de Glycine max e Solanum americanum. Planta Daninha, Viçosa, v. 30, n. 1, p. 87-95, 2012.

BRAZ, G. B. P. et al. Controle de solanáceas por herbicidas utilizados em algodoeiro. Revista Brasileira de Herbicidas, Mossoró, v. 10, n. 3, p. 190-199, 2011.

BRUUN, S. et al. A nitrogen mineralization model based on relationships for gross mineralization and immobilization. Soil Biology \& Biochemistry, Oxford, v. 38, n. 9, p. 2712-2721, 2006.

CANTARUTTI, R. B. et al. Avaliação da fertilidade do solo e recomendação de fertilizantes. In: NOVAIS, R. F. et al. (Eds.). Fertilidade do solo. Viçosa: Sociedade Brasileira da Ciência do Solo, 2007. v. 1, cap. 13 , p. $769-850$.

CAVALCANTE, V. S. et al. Biomassa e extração de nutrientes por plantas de cobertura. Revista 
Brasileira de Engenharia Agrícola e Ambiental, Campina Grande, v. 16, n. 5, p. 521-528, 2012.

CHACÓN, E. A. V. et al. Decomposição de fontes orgânicas e mineralização de formas de nitrogênio e fósforo. Revista Ceres, Viçosa, v. 58, n. 3, p. 373383, 2011.

CHEN, B. et al. Soil nitrogen dynamics and crop residues. A review. Agronomy for Sustainable Development, Paris, v. 34, n. 2, p. 429-442, 2014.

COOPER, J. et al. The future distribution and production of global phosphate rock reserves. Resources, Conservation and Recycling, Amsterdam, v. 57, n. 1, p. 78-86, 2011.

DAMON, P. M. et al. Crop residue contributions to phosphorus pools in agricultural soils: A review. Soil Biology and Biochemistry, Oxford, v. 74, s/n., p. 127-137, 2014.

ESPINDOLA, J. A. A. et al. Decomposição e liberação de nutrientes acumulados em leguminosas herbáceas perenes consorciadas com bananeira. Revista Brasileira de Ciência do Solo, Viçosa, v. 30, n. 2, p. 321-328, 2006.

GOVINDARAJAN, M. et al. One-pot fabrication of silver nanocrystals using Nicandra physalodes: A novel route for mosquito vector control with moderate toxicity on non-target water bugs. Research in Veterinary Science, Oxford, v. 107, s/ n., p. 95-101, 2016

HARRE, N. T. et al. Decay and nutrient release patterns of weeds following post-emergent glyphosate control. Weed Science, Lawrence, v. 62, n. 4, p. 588-596, 2014.

HOFFMAN, P. C. et al. El efecto de la madurez en la digestibilidad del FDN (fibra detergente neutro). Focus on Forage, Madison, v. 5, n. 15, p. 1-2, 2007.

IPPOLITO, J. A.; BARBARICK, K. A. A simple carbon-nitrogen assay for introductory soil science classes. Journal of Natural Resources and Life Sciences Education, Madison, v. 32, n. 1, p. 69-72, 2003.

KALBITZ, K. et al. Response of dissolved organic matter in the forest floor to long-term manipulation of litter and throughfall inputs. Biogeochemistry, Dordrecht, v. 86, n. 3, p. 301-318, 2007.

KISSMANN, K. G.; GROTH, D. Plantas infestantes e nocivas. 2. ed. São Paulo, SP: BASF, 2000.683 p.

LINDSEY, L. E. et al. Nitrogen release from weed residue. Weed Science, Lawrence, v. 61, n. 2, p. 334 $-340,2013$.

LONG, S. P. et al. Meeting the global food demand of the future by engineering crop photosynthesis and yield potential. Cell, Cambridge, v. 161, n. 1, p. 5666, 2015.

LORENZI, H. Manual de identificação e controle de plantas daninhas: plantio direto e convencional. 6. ed. Nova Odessa, SP: Instituto Plantarum, 2006. $339 \mathrm{p}$.

MAGALHÃES, J. A. et al. Composição bromatológica do capim-Marandu sob efeito de irrigação e adubação nitrogenada. Semina: Ciências Agrárias, Londrina, v. 36, n. 2, p. 933-942, 2015.

MALAVOLTA, E. et al. Avaliação do estado nutricional das plantas: princípios, métodos e técnicas de avaliação do estado nutricional. 2. ed. Piracicaba, SP: Potafos. 1997. 319 p.

MARSCHNER, H. Mineral nutrition of higher plants. 2. ed. London: Academic Press, 2012. 889 p.

MARTINS, T. A. et al. Acúmulo de matéria seca e macronutrientes por plantas de Merremia aegyptia. Planta Daninha, Viçosa, v. 28, Sup., p. 1023-1029, 2010.

MASCLAUX-DAUBRESSE, C. et al. Nitrogen uptake, assimilation and remobilization in plants: challenges for sustainable and productive agriculture. Annals of Botany, Oxford, v. 105, n. 7, p. 11411157,2010

MATOS, C. C. et al. Nicandra physalodes growth at different concentrations of N, P and K. Semina: Ciências Agrárias, Londrina, v. 36, n. 3, p. $1307-$ $1316,2015$.

MUKUNGU, N. A. et al. Solation and structural elucidation of compounds from the non-alkaloidal extract of Nicandra physaloides and the antimicrobial activity of withanicandrin. East and Central African Journal of Pharmaceutical Sciences, Nairobi, v. 16, n. 2, p. 49-53, 2013.

NEPOMUCENO, M. et al. Períodos de interferência das plantas daninhas na cultura da soja nos sistemas de semeadura direta e convencional. Planta Daninha, Viçosa, v. 25, n. 1, p. 43-50, 2007.

ORTEGA-VARGAS, E. et al. Date of pruning of Guazuma ulmifolia during the rainy season affects the availability, productivity and nutritional quality of forage during the dry season. Agroforestry Systems, Dordrecht, v. 87, n. 4, p. 917-927, 2013. 
RAY, D. K. et al. Yield trends are insufficient to double global crop production by 2050. PLoS ONE, San Francisco, v. 8, n. 6, p. e66428, 2013.

REGEHR, A. et al. Gross nitrogen mineralization and immobilization in temperate maize-soybean intercrops. Plant and Soil, Dordrecht, v. 391, n. 1, p. 353-365, 2015.

RENWICK, A. et al. Power in global agriculture: Economics, politics, and natural resources. International Journal of Agricultural Management, Exeter, v. 2, n. 1, p. 31-48, 2012.

RUFFO, M. L.; BOlleRO, G. A. Residue decomposition and prediction of carbon and nitrogen release rates based on biochemical fractions using principal-component regression. Agronomy Journal, Madison, v. 95, n. 4, p. 1034-1040, 2003.

SAKONNAKHON, S. P. N. et al. Weeds - friend or foe? The role of weed composition on stover nutrient recycling efficiency. Field Crops Research, Amsterdam, v. 97, n. 2-3, p. 238-247, 2006.

TILMAN, D. et al. Agricultural sustainability and intensive production practices. Nature, London, v. 418, n. 6898, p. 671-677, 2002.

TOMASSINI, T. C. B. et al. Gênero Physalis - uma revisão sobre vitaesteróides. Química Nova, São Paulo, v. 23, n. 1, p. 47-57, 2000.

VAN SOEST, P. J. et al. Methods for dietary fiber, neutral detergent fiber, nonstarch polysaccharides in relation to animal nutrition. Journal of Dairy Science, Chanpaign, v. 74, n. 10, p. 3583- 3597, 1991.

VAN VUUREN, D. P. et al. Phosphorus demand for the 1970-2100 period: A scenario analysis of resource depletion. Global Environmental Change, Oxford, v. 20, n. 3, p. 428-439, 2010.

VANCE, C. P. et al. Phosphorus acquisition and use: critical adaptations by plants for securing a nonrenewable resource. New Phytologist, Hoboken, v. 157, n. 3, p. 423-447, 2003.

VELAZQUEZ-JIMENEZ, L. H.; RANGELMENDEZ, J. R. Chemical and thermogravimetric analyses of raw and saturated agave bagasse main fractions with $\mathrm{Cd}(\mathrm{II}), \mathrm{Pb}(\mathrm{II})$, and $\mathrm{Zn}$ (II) Ions: adsorption mechanisms. Industrial \& Engineering Chemistry Research, Washington, v. 53, n. 20, p. 8332-8338, 2014.

WATANABE, $H$. et al. Environmental factors affecting germination of apple of Peru. Weed
Science, Lawrence, v. 50, n. 2, p. 152-156, 2002. $\mathrm{XU}, \mathrm{X}$. et al. Estimating a new approach of fertilizer recommendation across small-holder farms in China. Field Crops Research, Amsterdam, v. 163, s/n., p. 10-17, 2014.

YADVINDER-SINGH, $\mathrm{S}$. et al. Crop residue management for nutrient cycling and improving soil productivity in rice-based cropping systems in the tropics. Advances in Agronomy, San Diego, v. 85, n. 1, p. 269-407, 2005.

ZHOU, W. J. et al. Direct effects of litter decomposition on soil dissolved organic carbon and nitrogen in a tropical rainforest. Soil Biology \& Biochemistry, Oxford, v. 81, n. 1, p. 255-258, 2015.

ZÖRB, C. et al. Potassium in agriculture - status and perspectives. Journal of Plant Physiology, Jena, v. 171, n. 9, p. 656-669, 2014. 